\title{
Olive mild mosaic virus transmission by Olpidium virulentus
}

\author{
Carla M. R. Varanda • Susana Santos • \\ Maria Ivone E. Clara • Maria do Rosário Félix
}

Accepted: 7 January 2015

C) Koninklijke Nederlandse Planteziektenkundige Vereniging 2015

\begin{abstract}
The ability of Olpidium virulentus to vector Olive latent virus 1 (OLV-1), Olive mild mosaic virus (OMMV) and Tobacco necrosis virus D (TNV-D) was evaluated. Transmission assays involved zoospore acquisition of each virus, inoculation onto cabbage plant roots followed by viral detection. Assays revealed that these viruses are transmitted in the absence of the fungus, but the transmission rates of OMMV are much higher when OMMV is incubated with $O$. virulentus zoospores prior to inoculation, while the transmission rates of each OLV-1 and TNV-D do not change when they are incubated with the fungus. Our data shows that $O$. virulentus is an efficient vector of OMMV, greatly enhancing virus transmissibility, but not that of OLV-1 nor TNV-D. Prior studies have shown that another fungus, $O$. brassicae, also enhances OMMV transmission. To our knowledge, this is the first report of a plant virus, OMMV, being efficiently transmitted by two different species of fungi.
\end{abstract}

Keywords OMMV. Olpidium virulentus $\cdot$ Dual transmission

C. M. R. Varanda $(\bowtie) \cdot$ S. Santos $\cdot$ M. I. E. Clara

M. d. R. Félix

Laboratório de Virologia Vegetal, Instituto de Ciências

Agrárias e Ambientais Mediterrânicas, Universidade de

Évora, 7002-554 Évora, Portugal

e-mail: carlavaranda@uevora.pt
The alphanecroviruses Olive mild mosaic virus (OMMV) and Olive latent virus 1 (OLV-1) and the betanecrovirus Tobacco necrosis virus $D$ (TNV-D) are very common in Portuguese olive orchards reaching infection levels of $31 \%$ (Varanda et al. 2006) and frequently appearing in mixed infections (Varanda et al. 2010). These viruses are very similar and their differentiation is only possible through PCR - based assays using specific primers (Varanda et al. 2010) or genome sequencing.

Prior to the discrimination into different species, TNV was found to be vectored by $O$. brassicae 'sensu lato' (Temmink et al. 1970). Studies based on host specificity, ability to transmit certain plant viruses and molecular analysis of the complete rDNA-ITS regions have confirmed that Olpidium sp. that infect noncrucifer plants differ from those infecting crucifer plants thus leading to the nomenclature $O$. virulentus (Sahtiyanci) Karling for the non-crucifer strain and $O$. brassicae for the crucifer strain (Koganezawa et al. 2005). In view of the developments concerning TNV and $O$. brassicae recent speciations, much of the earlier data on virus vector transmission needs re-evaluation. Recently, a multiplex PCR assay was developed to discriminate the two species of Olpidium spp.(HerreraVasquez et al. 2009). Molecular identification has allowed the determination of $O$. brassicae as a vector of OMMV (Varanda et al. 2011b) and O. virulentus as a vector of Tobacco stunt virus, Pepino mosaic virus, of a dianthovirus causing the necrotic streak of fique and of Mirafiori lettuce big-vein virus and Lettuce big-vein 
associated virus (Sasaya and Koganezawa 2006; Alfaro-Fernandez et al. 2010; Gonzalez et al. 2010; Maccarone et al. 2010).

In this study we demonstrate $O$. virulentus ability to act as a vector of OMMV, suggesting that this species, together with $O$. brassicae, may have a role in the high dissemination of this virus within olive orchards.

An infectious transcript of OMMV cDNA clone obtained from the OMMV type strain, recovered from Olea europaea L. (Cardoso et al. 2005) and previously characterised OLV-1 and TNV-D (Cardoso et al. 2009) isolates, were used. OMMV and TNV-D isolates were maintained in Chenopodium murale and OLV-1 in $\mathrm{Ni}$ cotiana benthamiana plants. The leaves were ground in cold $0.1 \mathrm{M}$ sodium phosphate buffer $(1: 3 w / v)$, filtered, clarified in the presence of organic solvents, concentrated by differential centrifugation and further purified by ultracentrifugation through sucrose density gradient columns (Zhang et al. 1993). The recovery of the fungi through Chinese cabbage plants (Brassica campestris, Pekinensis group) from a field where horticultural crops had grown intensively (north of Portugal), as well as the observation of fungal structures in roots and isolation of single sporangium were performed as described previously (Varanda et al. 2011b). A single sporangium, was placed in a pot containing a mixture of sterile sand and vermiculite where 5 day old cabbage seedlings were growing and maintained in a growth chamber at 16$22{ }^{\circ} \mathrm{C}$ with a $16 \mathrm{~h}$ photoperiod for 1 month (Varanda et al. 2011b).
Zoospore populations were harvested from infected chinese cabbage plants. $\mathrm{Ca} .5 \times 10^{6}$ zoospores were lysed and total DNA was directly extracted using DNeasy Plant Mini Kit (Qiagen) following the manufacturer's instructions. The same procedure was made using lettuce (Lactuca sativa, cv. White boston) as bait plants.

A primer specific for $O$. virulentus (OLPvirF) and a primer specific for $O$. brassicae (OLPbraF) were used together with one common reverse primer (OLPR) in a multiplex PCR assay (Herrera-Vasquez et al. 2009). Amplified products were separated by electrophoresis in $1 \%$ agarose gel in $1 \times$ TBE buffer $(0.1 \mathrm{M}$ Tris, $0.09 \mathrm{M}$ boric acid, $1 \mathrm{mM}$ EDTA, $\mathrm{pH} 8.4$ ) at $80 \mathrm{~V}$ and stained with $0.2 \mu \mathrm{g} \mathrm{ml}^{-1}$ ethidium bromide. Amplicons were purified using GFX PCR DNA purification kit (GE Healthcare) and directly sequenced in both directions.

Transmission assays were performed as in Varanda et al. (2011b). Viral concentrations ranging from 0.07 to $150 \mu \mathrm{g} \mathrm{ml}^{-1}$ were tested. Plants were taken 6 days later, the roots washed extensively with a $1 \%$ SDS aqueous suspension and then with running tap water for $3 \mathrm{~h}$ before testing by DAS-ELISA (double antibody sandwich-enzyme linked immunosorbent assay) (Clark and Adams 1977) for the presence of virus. Ten pots containing 10 plants each were used in each experiment. Each experiment was repeated 3 times.

Typically $100 \mathrm{~g}$ of tissue infected with each virus yielded approximately the same amount, $c a .0 .3 \mathrm{mg}$ of purified virus, when purified from the indicator plants. Reinoculation of new healthy indicator plants as well as cabbage and lettuce plants, using purified virus particles,
Fig. 1 Root cells of cabbage plants observed under light microscope revealing typical stellate resting spores of O. virulentus

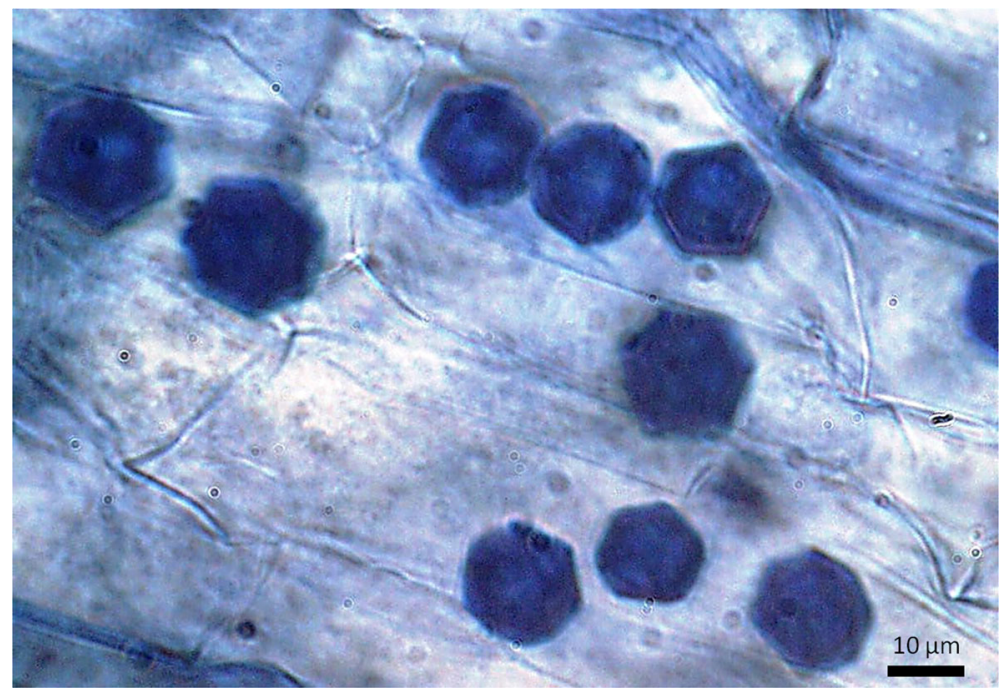




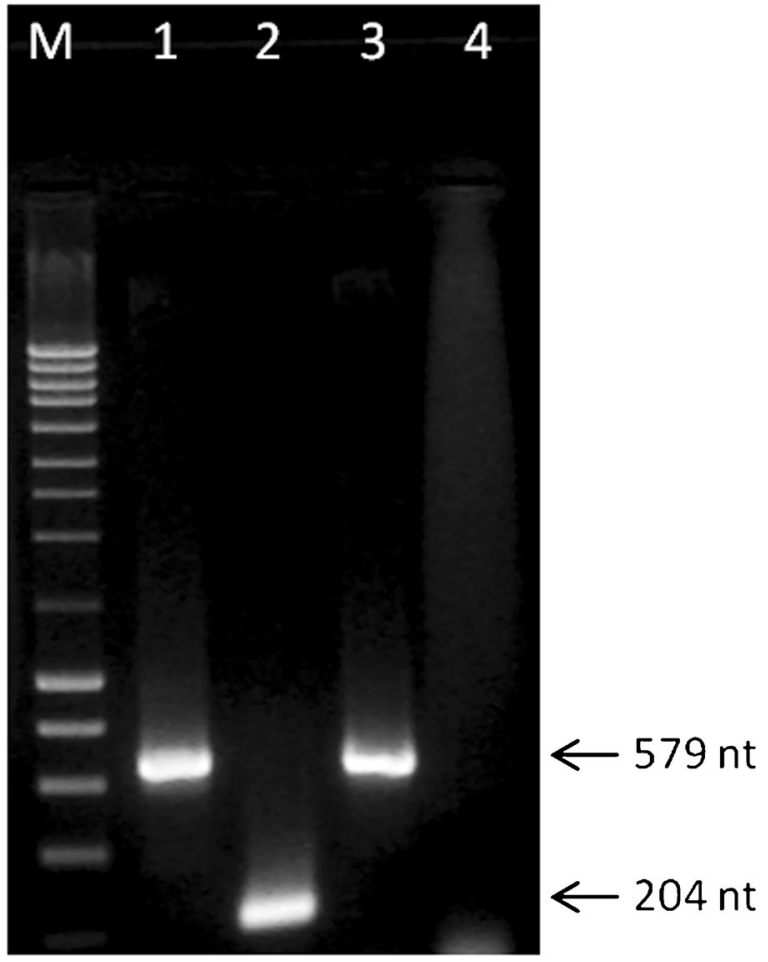

Fig. 2 Products of multiplex PCR assay applied to DNA extracted from fungal zoospores using specific primers for $O$. brassicae and for $O$. virulentus, separated on a $1 \%$ agarose gel. Lane $M$ : NZY ladder III; Lane 1: DNA from $O$. virulentus, as positive control; Lane 2: DNA from $O$. brassicae, as positive control; Lane 3: DNA of Olpidium species recovered from a field soil and used in virus transmission experiments in this study; Lane 4: water, as negative control. Size of generated amplicons are indicated on the right

revealed chlorotic and necrotic symptoms 2 to 3 days after inoculation, showing the high infectivity of the particles (data not shown).
Chinese cabbage and lettuce plants inoculated with a single sporangial culture showed abundant typical stellate resting spores (Fig. 1) that under appropriate conditions released zoospores showing a rapid and jerky movement. Although $O$. virulentus has been referred as a non-crucifer strain in opposition to $O$. brassicae (Sasaya and Koganezawa 2006; Herrera-Vasquez et al. 2009), O. virulentus easily infected the roots of both crucifer and non-crucifer hosts. This result was not completely unexpected as cabbage isolates have previously shown to infect lettuce and lettuce isolates have shown to infect cabbage (Jacobsen 1943; Sahtiyanci 1961; Koganezawa et al. 2005). In fact, due to this, the division into two different species according to their hosts was never consensual.

Multiplex PCR assays using primers specific for $O$. brassicae and for $O$. virulentus, produced a single amplified product of $c a$. 579 bp using either cabbage (Fig. 2) or lettuce plants (data not showed). Sequencing of the amplicons confirmed the identification of the fungal isolates as $O$. virulentus (data not shown).

Chinese cabbage plants were used in the transmission assays because their roots showed higher biomass and therefore a higher abundance of sporangia than lettuce.

Results of transmission assays show that each virus could infect plant roots with a $10 \%$ efficiency in the absence of $O$. virulentus at concentrations of $0.26 \mu \mathrm{g} \mathrm{ml}^{-1}$ of OLV-1 and $0.5 \mu \mathrm{g} \mathrm{ml}^{-1}$ of OMMV and of TNV-D and reached $100 \%$ transmission at $65 \mu \mathrm{g} \mathrm{ml}^{-1}, 2 \mu \mathrm{g} \mathrm{ml}^{-1}$ and $150 \mu \mathrm{g} \mathrm{ml}^{-1}$, for these viruses, respectively. However, acquisition of $2 \mu \mathrm{g} \mathrm{ml}^{-1}$ of OMMV by $O$. virulentus zoospores highly raised the level of transmission to $100 \%$ when compared to that

Table 1 'In vitro' transmission efficiency of OMMV, OLV-1 and TNV-D, in the presence/absence of $O$. virulentus

\begin{tabular}{lllllll}
\hline \multirow{2}{*}{ Virus concentration $(\mu \mathrm{g} / \mathrm{mL})$} & \multicolumn{2}{l}{ Transmission efficiency $(\%)^{\mathrm{a}}$} & & \\
\cline { 2 - 6 } & OMMV & OMMV + fungus & OLV-1 & OLV-1 + fungus & TNV-D & TNVD-D + fungus \\
\hline 0.13 & 0 & 0 & 0 & 0 & 0 & 0 \\
0.26 & 0 & 10 & 10 & 10 & 0 & 0 \\
0.5 & 10 & 30 & 10 & 10 & 10 & 10 \\
2 & 50 & 100 & 30 & 30 & 20 & 20 \\
50 & 100 & 100 & 60 & 60 & 20 & 20 \\
65 & 100 & 100 & 100 & 100 & 30 & 30 \\
150 & 100 & 100 & 100 & 100 & 100 & 100 \\
\hline
\end{tabular}

\footnotetext{
${ }^{a}$ Percentage of pots containing virus-infected cabbage plants, as evaluated by DAS-ELISA. Ten pots, each containing 10 plants, were used
} in each treatment. Values were consistent in 3 experiments 
of the $50 \mu \mathrm{g} \mathrm{ml}^{-1}$ observed in the absence of the fungus (Table 1). This shows that $O$. virulentus seems to be even a more efficient vector of OMMV than its other vector, $O$. brassicae, where $5 \mu \mathrm{g}$ account for a $86 \%$ efficiency of transmission (Varanda et al. 2011b). This is particular interesting as to our knowledge this is the first report of a virus that is transmitted by two different species of Olpidium sp. In contrast, presence or absence of the fungus did not influence the transmission of OLV-1 nor TNV-D indicating that the fungus is not a vector of these two viruses in cabbage. Further studies are needed to determine if these viruses are transmitted by the fungus to other hosts.

The mechanisms underlying transmission are not fully understood in most cases, however several studies have shown that the coat protein $(\mathrm{CP})$ of plant viruses plays an important role in transmission and particular amino acids are essential (van den Heuvel et al. 1999; Varanda et al. 2011a). Differences in fungal transmissibility of OMMV compared to that of OLV-1 and TNV-D, may lie in differences in specific CP sequences. OMMV CP shares $85.1 \%$ identity with that of TNV-D which would suggest a similar transmission behavior, however further studies are needed to reveal the mechanism(s) involved.

This study is the first report of OMMV transmission by $O$. virulentus already known to be transmissible by $O$. brassicae which may help to explain why OMMV, among the three viruses tested, presents the highest levels of infection in Portuguese olive orchards (Varanda et al. 2010).

This study contributes to a better understanding on virus vectors and has important implications in the management of OMMV associated diseases thus contributing to more successful control of the virus. Results here obtained suggest that OMMV contaminated substrates used in nurseries, especially if in presence of $O$. virulentus or $O$. brassicae, may lead to an extensive viral dissemination causing deleterious effects to plants.

\footnotetext{
Acknowledgments The authors would like to thank José Ángel Herrera-Vásquez (Universidad Politécnica de Valencia, Spain) for providing DNA from $O$. brassicae and $O$. virulentus to use as controls. Carla MR Varanda is recipient of a PhD fellowship from FCT, SFRH/BPD/76194/2011, financed by QREN - POPH Typology 4.1 - co-financed by MES national funding and The European Social Fund. This work has been supported by FEDER and National funds, through the Programa Operacional Regional do Alentejo (InAlentejo) Operation ALENT-07-0262-FEDER001871/ Laboratório de Biotecnologia Aplicada e Tecnologias Agro-Ambientais.
}

Conflicts of interest The authors declare no conflict of interest.

\section{References}

Alfaro-Fernandez, A., del Carmen Cordoba-Selles, M., Angel Herrera-Vasquez, J., del Carmen Cebrian, M., \& Jorda, C. (2010). Transmission of pepino mosaic virus by the fungal vector olpidium virulentus. Journal of Phytopathology, 158(4), 217-226. doi:10.1111/j.1439-0434.2009.01605.x.

Cardoso, J. M. S., Felix, M. R., Clara, M. I. E., \& Oliveira, S. (2005). The complete genome sequence of a new necrovirus isolated from Olea Europaea L. Archives of Virology, 150(4), 815-823. doi:10.1007/s00705-004-0453-1.

Cardoso, J. M. S., Felix, M. R., Clara, M. I. E., \& Oliveira, S. (2009). Complete genome sequence of a Tobacco necrosis virus $D$ isolate from olive trees. Archives of Virology, 154(7), 1169-1172. doi:10.1007/s00705-009-0414-9.

Clark, M. F., \& Adams, A. N. (1977). Characteristics of microplate method of enzyme linked immunosorbent assay for detection of plant viruses. Journal of General Virology, 34, 475-483. doi:10.1099/0022-1317-34-3-475.

Gonzalez, C., Osorio, D. L., Cepero de Garcia, M. C., Sastoque, L., Beltran, C., \& Cotes, A. M. (2010). Morphological and molecular characterization of Olpidium virulentus, the fungal vector of the Macana virus disease in Colombia. Phytopathology, 100(6), S42-S42.

Herrera-Vasquez, J. A., Cebrian, M. D., Alfaro-Fernandez, A., Cordoba-Selles, M. D., \& Jorda, C. (2009). Multiplex PCR assay for the simultaneous detection and differentiation of Olpidium bornovanus, O. brassicae, and O. virulentus. Mycological Research, 113, 602-610. doi:10.1016/j.mycres.2009.01.007.

Jacobsen, B. (1943). Studies on Olpidium brassicae (Wor.) Dang. Meddr. Vet. Hejsk. plantpat. Afd. Kbh., 24, 1-53.

Koganezawa, H., Inoue, H., \& Sasaya, T. (2005). Host specificity and multiplication of eight isolates of Olpidium brassicae sensu lato and its related Olpidium sp. Bulletin of the National Agricultural Research Center Western Region, 4, 21.

Maccarone, L. D., Barbetti, M. J., Sivasithamparam, K., \& Jones, R. A. C. (2010). Molecular genetic characterization of olpidium virulentus isolates associated with Big-vein diseased lettuce plants. Plant Disease, 94(5), 563-569. doi:10. 1094/pdis-94-5-0563.

Sahtiyanci, S. (1961). Studien uber einige wurzel-parasitare Olpidiaceen. Archiv für Mikrobiologie, 41, 187-228.

Sasaya, T., \& Koganezawa, H. (2006). Molecular analysis and virus transmission tests place Olpidium virulentus, a vector of Mirafiori lettuce big-vein virus and tobacco stunt virus, as a distinct species rather than a strain of Olpidium brassicae. Journal of General Plant Pathology, 72, 6.

Temmink, J. H. M., Campbell, R. N., \& Smith, P. R. (1970). Specificity and site of in vitro acquisition of Tobacco necrosis virus by zoospores of olpidium brassicae. Journal of General Virology, 9, 201-209.

van den Heuvel, J., Hogenhout, S. A., \& van der Wilk, F. (1999). Recognition and receptors in virus transmission by arthropods. Trends in Microbiology, 7, 71-76. doi:10.1016/s0966842x(98)01434-6. 
Varanda, C. M. R., Félix, M. R. F., Leitão, F., Sismeiro, R., \& Clara, M. I. E. (2006) Application of Reverse Transcription Polymerase Chain Reaction to screen a collection of clones of Olea europaea L. for the presence of necroviruses (Tombusviridae). In 8th Conference of the European Foundation for Plant Pathology \& British Society of Plant Pathology Presidential Meeting 2006, Denmark.

Varanda, C. M. R., Cardoso, J. M. S., Félix, M. R. F., Oliveira, S., \& Clara, M. I. E. (2010). Multiplex RT-PCR for detection and identification of three necroviruses that infect olive trees. Journal of Plant Pathology, 127, 161-164.

Varanda, C. M. R., Félix, M. R., Soares, C. M., Oliveira, S., \& Clara, M. I. E. (2011a). Specific amino acids of Olive mild mosaic virus coat protein are involved on transmission by Olpidium brassicae. Journal of General Virology, 92, 2209-2213.

Varanda, C. M. R., Silva, M., Félix, M. R., \& Clara, M. I. E. (2011b). Evidence of Olive mild mosaic virus transmission by Olpidium brassicae. European Journal of Plant Pathology, 130, 165-172.

Zhang, L., French, R., \& Langenberg, W. G. (1993). Molecular cloning and sequencing of the coat protein gene of a Nebraskan isolate of Tobacco necrosis virus. The deduced coat protein sequence has only moderate homology with those of strain A and strain D. Archives of Virology, 132, 291-305. doi:10.1007/bf01309540. 